Diabetologia (1994) 37: 1097-1104

\title{
Expression of human GLUT4 in mice results in increased insulin action
}

\author{
R.O. Deems ${ }^{1}$, J. L. Evans ${ }^{1}$, R. W. Deacon ${ }^{1}$, C.M. Honer ${ }^{1}$, D. T. Chu ${ }^{1}$, K. Bürki ${ }^{2}$, W. S. Fillers ${ }^{1}$, D. K. Cohen ${ }^{1}$, \\ D. A. Young \\ ${ }^{1}$ Diabetes Department, Preclinical Research, Sandoz Research Institute, Sandoz Pharmaceuticals Corporation, East Hanover, \\ New Jersey, USA \\ ${ }^{2}$ Preclinical Research, Sandoz Pharma Ltd., Basel, Switzerland
}

Summary Glucose metabolism was evaluated in transgenic mice expressing the human GLUT 4 glucose transporter. Fed GLUT 4 transgenic mice exhibited a $32 \%$ and $56 \%$ reduction in serum glucose and insulin and a $69 \%$ and $33 \%$ increase in non-esterified fatty acid and lactate levels, respectively. Transgenic mice exhibited a significant increase in whole-body glucose disposal during a euglycaemic-hyperinsulinaemic clamp. Insulin-stimulated glucose uptake in isolated soleus muscles and adipocytes was greater in transgenic compared to control mice due to increased basal glucose uptake. Transgenic mice displayed increased glycogen levels in liver and gastrocnemius muscle, and increased insulin-stimulated ${ }^{14} \mathrm{C}$-glycogen accumulation in isolated soleus muscle. We conclude that over-expression of the GLUT 4 glucose transporter in mice results in 1) an increase in whole-body glucose disposal and storage, and 2) an increase in both basal and insulin-stimulated glucose uptake and disposal in vitro. These changes resulted in the reduction of serum glucose and insulin levels. These results provide direct evidence that glucose transport (and GLUT 4 per se) plays a significant role in regulating wholebody glucose homeostasis. Additionally, these data support the idea that pharmacological strategies directed at increasing the expression of GLUT 4 protein may have beneficial (hypoglycaemic) effects in the diabetic state. [Diabetologia (1994) 37: 1097-1104]

Key words GLUT 4 transgenic mice, euglycaemichyperinsulinaemic clamps, glucose transport, insulin action, glycogen.
Insulin resistance as demonstrated by decreased insulin-stimulated glucose uptake and disposal is a characteristic feature of obesity and non-insulin-dependent diabetes mellitus (NIDDM) $[1,2]$. Impaired insulin-stimulated glucose uptake has been observed in both adipose tissue and skeletal muscle from obese and diabetic rodents and humans [3-7]. Glucose transport is mediated by a family of facilitative

Received: 9 February 1994

and in revised form: 8 June 1994

Corresponding author: Dr. R. O. Deems, Sandoz Research Institute, Diabetes Department, 404/2, 59 Route 10, East Hanover, NJ 07936, USA

Abbreviations: NIDDM, Non-insulin-dependent diabetes mellitus; GLUT, glucose transporter; TBS, Tris-buffered saline; NEFA, non-esterified fatty acid; w/v, weight/volume; PFK, phosphofructokinase. glucose transport proteins $[8,9]$. GLUT 1 is present in skeletal muscle and fat and is primarily responsible for constitutive (basal) glucose uptake. GLUT 4 is the most abundant transporter isoform in these insulin-sensitive tissues, and is responsible for the vast majority of insulin-stimulated glucose transport [1012]. Under basal conditions, GLUT 4 is present in a pool of vesicles localized to intracellular membranes. Following insulin stimulation or exercise, these vesicles are rapidly recruited to the plasma membrane [13-16], along with additional vesicle-associated proteins that may be involved in the regulation of vesicular trafficking [17-19]. In adipocytes and muscle, the redistribution of GLUT 4 can quantitatively account for the increase in insulin-stimulated glucose transport [20-22].

Considerable research has been directed toward determining whether the expression of GLUT 4 is altered in obesity or NIDDM or both. What has be- 
come clear from studies evaluating rodent models of diabetes, and from human studies, is that GLUT 4 expression is subject to tissue-specific regulation. In streptozotocin-treated rats, the amount of GLUT 4 in skeletal muscle is unaltered, but is reduced by more than $90 \%$ in adipocytes [23, 24]. In Zucker diabetic rats, which are insulin resistant, hyperinsulinaemic, and obese, GLUT 4 is also significantly reduced in adipocytes [25]. Most studies, but not all [25], report that GLUT 4 is unchanged in skeletal muscle [26-29]. This may be related to the extent of the diabetic state. Similarly, in obese humans and those with NIDDM, the level of GLUT 4 protein is markedly reduced in adipocytes [3, 4], but not in skeletal muscle [30-32]. Thus, data from rodent models and humans point to a mechanism other than an absolute reduction in GLUT 4 as the principal reason for impaired insulin-stimulated glucose transport in skeletal muscle, although it could be sufficient to account for the impairment in adipose tissue.

Whether or not a reduction in GLUT 4 expression is a significant factor leading to or resulting from insulin resistance associated with obesity or NIDDM, the central role of this facilitative transporter in mediating insulin-stimulated glucose transport suggests that it might be important in regulating whole-body glucose homeostasis [33]. Thus, it is intriguing to consider a novel therapeutic strategy for those disorders that emphasize the selective positive regulation of GLUT 4 protein levels. In an attempt to evaluate the physiological consequences of this approach, our group has recently reported the development of transgenic mice that express the human GLUT 4 glucose transporter gene under the control of its own promoter [34]. This transgene is expressed tissue specifically with the quantitatively greatest expression (mRNA and protein) in heart, skeletal muscle, and adipose tissue, respectively. Expression of the human GLUT 4 protein results in a significant reduction in serum glucose and insulin levels, and an increase in lactate [34]. The purpose of the present study was to further examine the impact on carbohydrate and lipid metabolism of human GLUT 4 expression in mice. Specifically, whole-body glucose disposal was assessed by employing the euglycaemic-hyperinsulinaemic clamp. Additionally, basal and insulin-stimulated glucose uptake were assessed in isolated soleus muscle and adipocytes. Finally, glycogen metabolism was assessed by measuring ${ }^{14} \mathrm{C}$-glycogen accumulation from ${ }^{14} \mathrm{C}$-glucose in isolated muscle, along with the determination of tissue glycogen levels.

\section{Materials and methods}

Animals. The production of mice expressing the human GLUT 4 gene has been described previously [34]. Adult male and female hemizygous mice from a single GLUT 4 transgenic foun- der (approximately 14 copies of the human GLUT 4 gene) were used in all studies described here. Animals were housed under standard laboratory conditions with a $12: 12 \mathrm{~h}$ light:dark cycle and were fed Purina rodent chow ad libitum, except when fasted overnight.

Western blot analysis. Tissues were homogenized at $0-4^{\circ} \mathrm{C}$ in a buffer containing $20 \mathrm{mmol} / \mathrm{l} \mathrm{HEPES}$ ( $\mathrm{pH} 7.4$ ), $0.25 \mathrm{~mol} / \mathrm{l} \mathrm{su}-$ crose, $3 \mathrm{mmol} / 1$ dithiothreitol, $1 \mathrm{mmol} / 1 \mathrm{EDTA}, 0.1 \mathrm{mmol} / \mathrm{l}$ PMSF and leupeptin, aprotinin and pepstatin $A$, each at $100 \mu \mathrm{g} / \mathrm{ml}$. Cell homogenates were layered on a $1.2 \mathrm{mmol} / \mathrm{l} \mathrm{su}-$ crose cushion and centrifuged at $100,000 \times g$ for $1 \mathrm{~h}$. Total membranes above the interface were collected and sedimented by centrifugation at $200,000 \times g$ for $1 \mathrm{~h}$ at $4^{\circ} \mathrm{C}$, and resuspended in homogenization buffer. The protein concentration of each sample was determined by the Coomassie Brilliant Blue method (Pierce, Rockford, IIl., USA) with bovine albumin as standard. Equal amounts of total membrane protein were subjected to $10 \%$ SDS-polyacrylamide gel electrophoresis and electrophoretically transferred to nitrocellulose filters. Membranes were blocked for $2 \mathrm{~h}$ with $4 \%$ Carnation low-fat instant milk in Tris-buffered saline (TBS) containing $0.02 \%$ Tween, followed by incubation at room temperature for $16 \mathrm{~h}$ with the $1 \mathrm{~F} 8$ monoclonal antibody (East Acres Biologicals, Southbridge, Mass., USA), specific for the GLUT 4 glucose transporter protein [35]. Blots were then washed for $10 \mathrm{~min}$ five times in TBS and incubated for $3 \mathrm{~h}$ in TBSTween-dry milk with ${ }^{125}$ I-labelled protein A (Amersham Corp., Arlington Heights, Ill., USA) with horseradish peroxidase-conjugated goat anti-mouse IgG. After five further washes, immunospecific bands were detected. Bands were evaluated by exposure to phosphor screens followed by visualization and quantitation using a PhosphorImager with ImageQuant software (Molecular Dynamics, Sunnyvale, Calif., USA).

Metabolic analyses. Serum was obtained via cardiac puncture from fed normal and transgenic female mice anaesthetized with $\mathrm{CO}_{2}$. Glucose and lactate levels were analysed with glucose oxidase and lactate oxidase, respectively, using an automated analyzer (Yellow Springs Instruments, YSI 27 or 2700 , Yellow Springs, Ohio, USA). Non-esterified fatty acid (NEFA) levels were measured using the acyl-CoA synthetase and acyl-CoA oxidase method (Wako Pure Chemical Industries, Richmond, Va., USA). Insulin was measured in whole serum by radioimmunoassay employing a guinea-pig anti-rat insulin antibody, ${ }^{125} \mathrm{I}$-porcine insulin, rat insulin standards, and polyethylene glycol-accelerated 2 nd antibody precipitation. The sensitivity of this assay is approximately $0.1 \mu \mathrm{U} / \mathrm{ml}$, and the inter- and intra-assay coefficients of variation are typically $7.0 \%$ and $8.0 \%$, respectively.

Euglycaemic-hyperinsulinaemic clamp. Cannulas were surgically implanted [36] into the jugular vein and carotid artery of overnight $(18 \mathrm{~h})$ fasted female mice anaesthetized with sodium pentobarbital $(50 \mathrm{mg} / \mathrm{kg}$ ). Animals remained anaesthetized for the duration of the study. Anaesthesia during the clamp was maintained by a low dose of isofluorane $(0.2-0.5 \%$ volume). Insulin and glucose were infused into the jugular vein; the carotid artery was used for blood sampling. Insulin ( $3 \mathrm{mU}^{\cdot} \mathrm{kg}^{-1} \mathrm{~min}^{-1}$ ) was infused at a rate of $10 \mu \mathrm{l} / \mathrm{min}$, after a priming dose of $20 \mu \mathrm{l} / \mathrm{min}$ for the first $10 \mathrm{~min}$. Blood glucose levels were determined at 5-min intervals for $120 \mathrm{~min}$. A variable rate of glucose (dextrose, $2 \% \mathrm{w} / \mathrm{v}$ ) was infused to maintain blood glucose levels at approximately $5-5.6 \mathrm{mmol} / \mathrm{l}$. At the conclusion of the experiment, animals were killed with an overdose of anaesthesia. 
2-Deoxyglucose uptake in isolated muscle. 2-Deoxyglucose uptake was assayed in isolated muscle as described previously [37]. Briefly, soleus muscles from $18 \mathrm{~h}$ fasted male mice were surgically excised and incubated for $15 \mathrm{~min}$ at $37^{\circ} \mathrm{C}$ in KrebsHenseleit buffer. The muscles were then incubated for $60 \mathrm{~min}$ in Erlenmeyer flasks in media containing $2-\left[{ }^{3} \mathrm{H}\right]$ deoxy-D-glucose ( $5 \mathrm{mmol} / \mathrm{l}$ final concentration) in the absence or presence of insulin as indicated. Following incubation, muscles were homogenized and processed for scintillation counting.

\begin{abstract}
${ }^{3} H$-glucose incorporation into lipid. Adipocytes were isolated from the epididymal fat pads of fed control and transgenic mice by collagenase digestion [38]. There was no significant difference in cell size between normal control and transgenic mice as determined by electron microscopy of an aliquot of adipocytes corresponding to approximately $0.15 \%$ of the total number employed for the assay (data not shown). Cells ( $2 \%$ $\mathrm{v} / \mathrm{v}$ final concentration corresponding to approximately $6 \times 10^{4}$ cells $/ \mathrm{ml}$ ) were preincubated for $30 \mathrm{~min}$ at $37^{\circ} \mathrm{C}$ with $1 \mathrm{U} / \mathrm{ml}$ adenosine deaminase, which was added to remove endogenous adenosine [39], and insulin as indicated. Adenosine deaminase did not affect the fragility of the adipocytes as evidenced by the absence of free fat droplets. Following preincubation, $\left[3-{ }^{3} \mathrm{H}\right]$-D-glucose $(0.5 \mu \mathrm{Ci} / \mathrm{ml}, 50 \mu \mathrm{mol} / \mathrm{l}$ final concentrations) was added, and the incubation continued for $60 \mathrm{~min}$. Incubations were terminated by the addition of $5 \mathrm{ml}$ of a toluenebased scintillant to each reaction vessel. Incorporation of ${ }^{3} \mathrm{H}$ glucose into cellular lipid (a reliable indicator of glucose transport under these conditions) was determined by liquid scintillation counting following overnight phase-separation at $4{ }^{\circ} \mathrm{C}$. Under these assay conditions, the radioactivity associated with water-soluble molecules (including unincorporated ${ }^{3} \mathrm{H}$ glucose) is not counted to a significant degree [40].
\end{abstract}

Glycogen accumulation. Glycogen accumulation in isolated soleus muscle was determined as described previously [41]. Soleus muscles were isolated from $18 \mathrm{~h}$ fasted normal and transgenic male mice. Insulin was added to the incubation media as indicated.

Tissue glycogen. Glycogen was determined by a modification of the method of Chan and Exton [42]. Tissue samples for glycogen analysis were rapidly frozen in liquid nitrogen, and stored at $-70^{\circ} \mathrm{C}$. Approximately $100 \mathrm{mg}$ of each tissue was extracted with $1 \mathrm{ml}$ of ice-cold $30 \%(\mathrm{w} / \mathrm{v})$ perchloric acid for $1 \mathrm{~h}$ at $4{ }^{\circ} \mathrm{C}$. Following centrifugation in a microfuge, $10 \mu \mathrm{l}$ of the supernatant was spotted on 7 -mm Whatman $3 \mathrm{MM}$ paper disks (Hillsboro, Oregon, USA). The disks were washed three times in $66 \%$ EtOH for $15 \mathrm{~min}$. The filters were dried and placed into wells of a 96-well microtiter plate along with $100 \mu \mathrm{l}$ acetate buffer containing $0.1 \mu \mathrm{g} / \mu \mathrm{l}$ amyloglucosidase $(53 \mathrm{U} / \mathrm{mg})$. The plate was incubated for 90 min at $37^{\circ} \mathrm{C}$ after which time $50 \mu \mathrm{l}$ of the incubation mixture was assayed for glucose using glucose oxidase (Ciba-Corning/Gilford, \#S1004B, Oberlin, Ohio, USA). The perchloric acid pellets remaining after centrifugation were digested overnight at room temperature with 0.8 $\mathrm{N} \mathrm{NaOH}$ and for an additional $1 \mathrm{~h}$ at $60^{\circ} \mathrm{C}$, and assayed for protein content [43].

\section{Statistical analyses}

Statistical significance was assessed by the Student's $t$-test or by ANOVA followed by Student's $t$-test for individual comparisons.

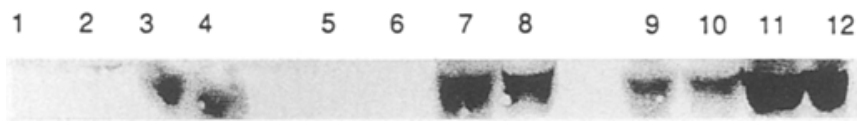

Fig. 1. Western blot analysis of GLUT 4 protein content of total membranes from control and GLUT 4 transgenic mice.Total membrane samples from epididymal fat $(15 \mu \mathrm{g}$, lanes 1-4), skeletal muscle (25 g, lanes 5-8) and heart ( $25 \mathrm{~g}$, lanes 9-12) from two control (lanes 1,2,5,6,9,10) and two GLUT 4 transgenic mice (lanes $3,4,7,8,11,12$ ) were electrophoresed and immunoblotted with the 1F8 monoclonal antibody

Table 1. Serum metabolite levels in normal and GLUT 4 transgenic female mice in the fed state

\begin{tabular}{lllll}
\hline & $\begin{array}{l}\text { Glucose } \\
(\mathrm{mmol} / \mathrm{l})\end{array}$ & $\begin{array}{l}\text { Lactate } \\
(\mathrm{mmol} / \mathrm{l})\end{array}$ & $\begin{array}{l}\text { Insulin } \\
(\mathrm{pmol} / \mathrm{l})\end{array}$ & $\begin{array}{l}\text { NEFA } \\
(\mathrm{mEq} / \mathrm{l})\end{array}$ \\
\hline $\begin{array}{l}\text { Control } \\
(n=6)\end{array}$ & $13.4 \pm 0.5$ & $7.7 \pm 0.3$ & $89.4 \pm 15.6$ & $1.6 \pm 0.1$ \\
$\begin{array}{l}\text { Transgenic } \\
(n=5)\end{array}$ & $9.0 \pm 0.5^{\mathrm{b}}$ & $10.2 \pm 0.6^{\mathrm{b}}$ & $39.6 \pm 13.2^{\mathrm{a}}$ & $2.7 \pm 0.1^{\mathrm{b}}$ \\
\hline
\end{tabular}

Results are expressed as mean \pm SEM for five to six mice per group. ${ }^{\mathrm{a}} p<0.05,{ }^{\mathrm{b}} p<0.001$, compared to control

\section{Results}

Western blot analysis. The level of expression of GLUT 4 glucose transporter protein (human plus murine) was evaluated by Western blotting with the anti-GLUT 4 monoclonal antibody IF8 of total membrane proteins isolated from epididymal adipose tissue, cardiac and skeletal muscle (hindlimb), liver, brain, kidney and small intestine of transgenic and control mice. Antibody IF8 binds both human and mouse GLUT 4 proteins. GLUT 4 protein was detected as a broad band of approximately $45-50 \mathrm{kDa}$ (Fig.1). In comparison to controls, transgenic animals had at least twofold greater expression of GLUT 4 protein in adipose tissue and three to fourfold greater expression in skeletal and cardiac muscle. Levels of GLUT 4 protein were substantially greater in heart than in skeletal muscle.

Metabolic analyses. Serum levels of glucose, lactate, insulin, and NEFA from fed control and transgenic mice are presented in Table 1. Glucose and insulin levels were significantly reduced by $32 \%$ and $56 \%$, respectively, in transgenic animals compared to controls. Lactate and NEFA levels were increased by $33 \%$ and $69 \%$, respectively, in transgenic vs control mice.

Euglycaemic-hyperinsulinaemic clamp. Whole-body insulin action was evaluated in five GLUT 4 transgenic mice and five control littermates. Glucose levels were clamped at approximately $5.5 \mathrm{mmol} / 1$. The mean glucose levels for the interval of 80-120 min were comparable for control and transgenic mice (Table 2). During this interval the glucose infu- 
Table 2. Blood glucose and glucose infusion rates (GIR) in 18 $\mathrm{h}$ fasted control and GLUT 4 transgenic mice during euglycaemic hyperinsulinaemic clamps

\begin{tabular}{lll}
\hline & $\begin{array}{l}\text { Glucose } \\
(\mathrm{mmol} / \mathrm{L})\end{array}$ & $\begin{array}{l}\mathrm{GIR} \\
\left(\mathrm{mg} \cdot \mathrm{kg}^{-1} \cdot \mathrm{min}^{-1}\right)\end{array}$ \\
\hline Control & $5.7 \pm 0.4$ & $10.3 \pm 3.4$ \\
$\begin{array}{l}\text { GLUT4 } \\
\text { Transgenic }\end{array}$ & $5.4 \pm 0.2$ & $35.6 \pm 11.3^{\mathrm{a}}$ \\
\hline
\end{tabular}

Insulin $\left(3 \mathrm{mU} \cdot \mathrm{kg}^{-1} \cdot \mathrm{min}^{-1}\right)$ was infused for $120 \mathrm{~min}$ with a variable rate of glucose infusion to maintain blood glucose levels at approximately $5.5 \mathrm{mmol} / 1$. Results are expressed as mean \pm SEM from 80 to $120 \mathrm{~min}$ of the clamp, for five mice per group ${ }^{\mathrm{a}} p<0.01$, compared to control

sion rate attained steady state, and was significantly increased in transgenic mice $(p<0.01$, Table 2$)$.

2-Deoxy-glucose uptake in muscle. The basal rate of 2-deoxyglucose uptake in isolated soleus muscles from transgenic mice was approximately 1.4 times higher compared to normal controls (Fig.2), although this difference did not reach statistical significance $(p<0.1)$. In controls, insulin $(0,0.72,72 \mathrm{nmol} / \mathrm{l})$ stimulated 2-deoxyglucose uptake by approximately 1.6-fold. In transgenics, insulin stimulated 2-deoxyglucose uptake by approximately 2 -fold relative to transgenic basal uptake, and by approximately 4-fold relative to control basal uptake.

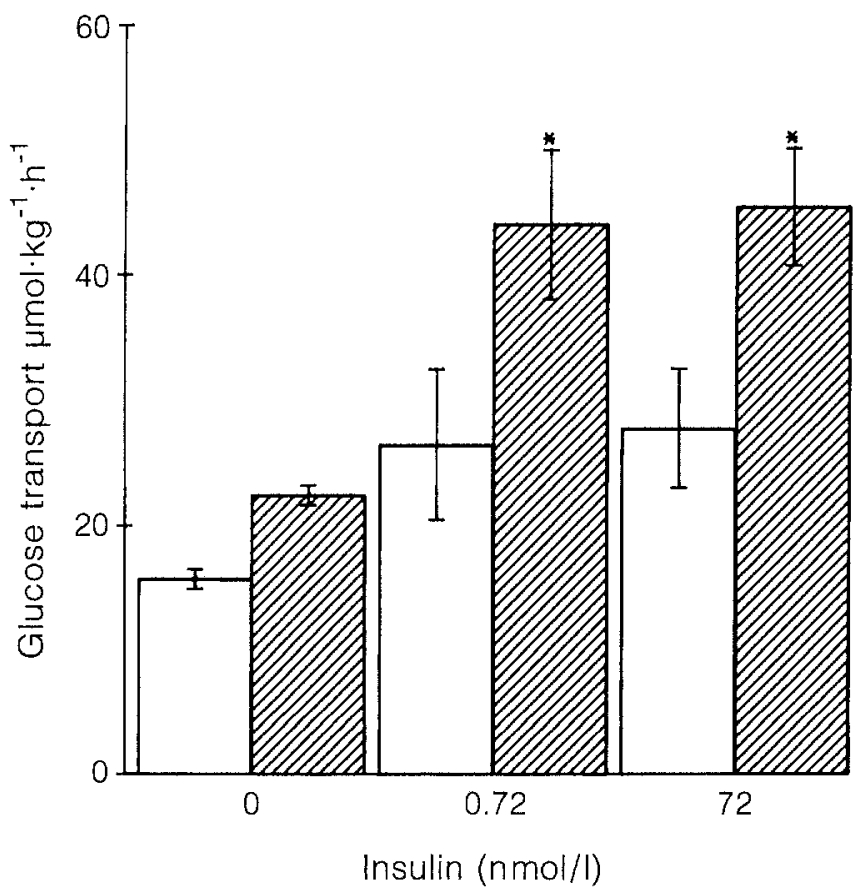

Fig. 2. 2-deoxyglucose uptake in isolated soleus muscles from control $\square$ and GLUT 4 transgenic mice $\square$. Soleus muscles were isolated from $18 \mathrm{~h}$ fasted mice and incubated in the presence or absence of insulin, as indicated. Results are expressed as mean \pm SEM for 7-10 muscles per group. " $p<0.05$, compared to respective control
${ }^{3} \mathrm{H}$-glucose incorporation into lipid. Glucose uptake was also assessed in isolated adipocytes. In the absence of insulin, basal glucose uptake was 3.2 times higher in transgenic mice as compared to control littermates (Fig. 3). In littermates, glucose uptake was stimulated by approximately 1.7 and 5.8 -fold by 50 $\mathrm{pmol} / \mathrm{l}$ and $8 \mathrm{nmol} / \mathrm{l}$ insulin, respectively. Despite elevated basal glucose uptake, the transgenics maintained their ability to respond to insulin. In transgenics, glucose uptake was increased by insulin by 1.8 and 4.0 -fold (compared to transgenic basal uptake), and by 5.8 and 12.7-fold (compared to control basal uptake).

Glycogen accumulation. The incorporation of ${ }^{14} \mathrm{C}$ glucose into glycogen in isolated soleus muscles from transgenic mice was significantly higher compared to control littermates under basal and insulin-stimulated conditions. Basal ${ }^{14} \mathrm{C}$-glycogen accumulation in GLUT 4 transgenics was elevated approximately 2.5 -fold compared to their control littermates (Fig. 4). In controls, ${ }^{14} \mathrm{C}$-glucose into glycogen was stimulated 6-8-fold by insulin. In transgenics, insulin stimulated ${ }^{14} \mathrm{C}$-glucose into glycogen by approximately 5.6-10-fold relative to transgenic basal incorporation, and by approximately 10-18-fold relative to control basal incorporation. The net result was that insulin-stimulated ${ }^{14} \mathrm{C}$-glycogen accumulation was between 1.5 and 2.6-fold above control levels.

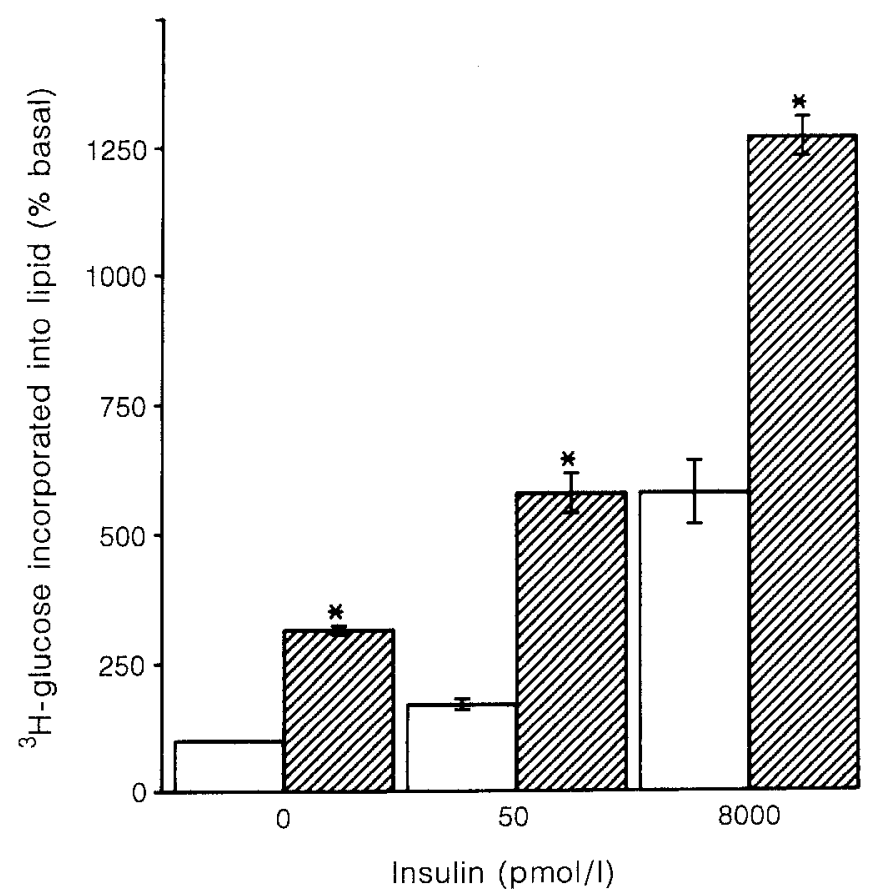

Fig. 3. ${ }^{3} \mathrm{H}$-glucose incorporation in isolated adipocytes from control $\square$ and transgenic mice $\square$. Adipocytes were isolated from mice and incubated in the presence or absence of insulin, as indicated. Results are expressed as the mean \pm SEM for four replications. " $p<0.01$, compared to respective control 


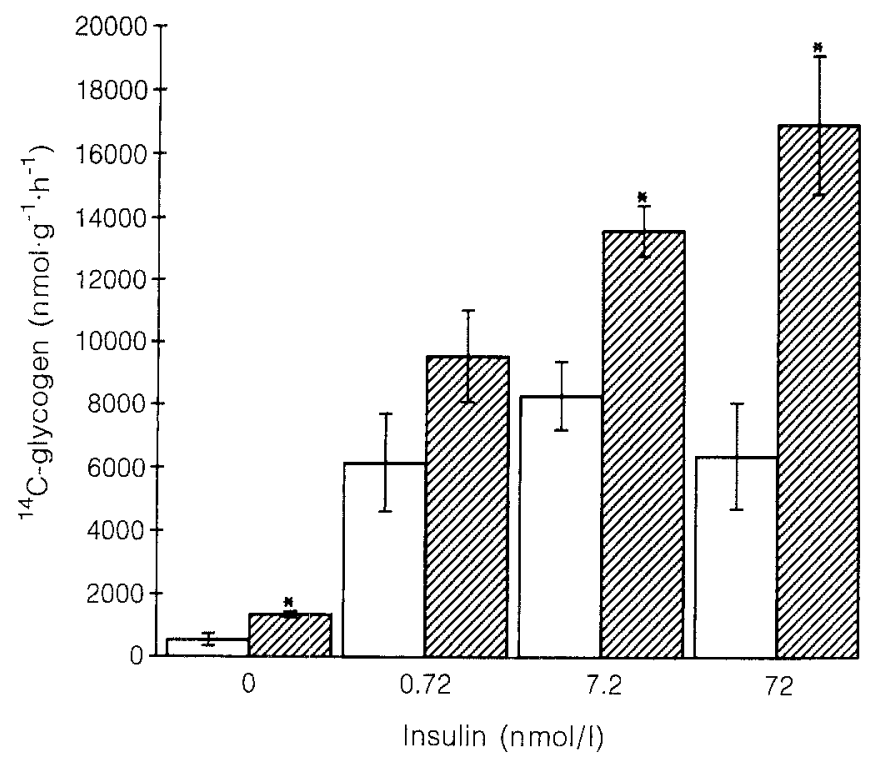

Fig. 4. ${ }^{14} \mathrm{C}$-glycogen accumulation in isolated soleus muscles from $18 \mathrm{~h}$ fasted control $\square$ and GLUT 4 transgenic $\square$ male mice. Animals were anaesthetized with $\mathrm{CO}_{2}$ and soleus muscles were immediately excised and processed as described in methods. Muscles were incubated in the presence or absence of insulin (nmol/1), as indicated. $n=3-4$ tissues per group ${ }^{*} p<0.05$, compared to respective control
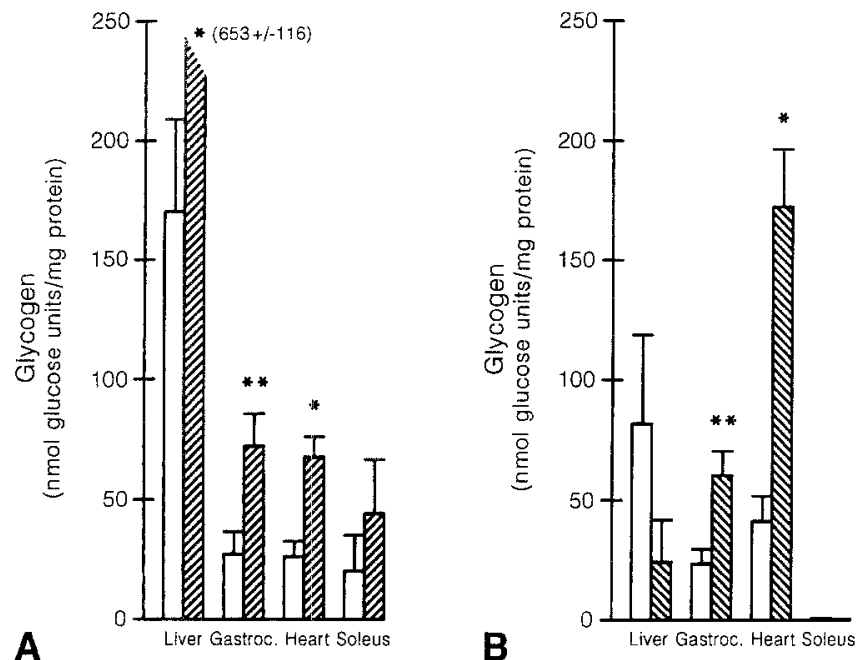

Fig. 5 A, B. Total glycogen levels in fed or fasted female control $\square$ and GLUT 4 transgenic mice $\square$. Fed (A) or 18 -h fasted (B) animals were anaesthetized with $\mathrm{CO}_{2}$ and tissues were immediately excised and processed as described in methods. $n=5-6$ animals per group ${ }^{*} p<0.05,{ }^{* * *} p<0.01$, compared to control

Tissue glycogen. In mice fed ad libitum, glycogen levels were significantly elevated in liver ( 4-fold), heart $(\sim 2.5$-fold $)$, and gastrocnemius muscles $(\sim 2.5$ fold) from transgenic mice compared to littermates (Fig.5). No statistically significant differences between groups were observed in the glycogen levels of soleus muscles. After an overnight fast, liver glycogen was substantially depleted in both transgenic and control mice and was no longer significantly different
(Fig.5). In contrast, fasting had no significant effect (compared to fed animals) on glycogen in gastrocnemius muscle from either group and remained significantly higher ( $\sim 2$-fold) in transgenic vs control mice. Interestingly, fasting had no significant effect on cardiac muscle glycogen in control littermates, but produced an approximate 3 -fold increase in glycogen in transgenic mice.

\section{Discussion}

Tissue-specific overexpression of the GLUT $4 \mathrm{glu}$ cose transporter in mice resulted in a pronounced increase in glucose utilization. The transgene was expressed in insulin-sensitive tissues of muscle, and to a lesser extent, fat. Enhanced glucose utilization was manifested by a significant increase in the wholebody glucose infusion rate during a euglycaemic hyperinsulinaemic clamp and by increased glucose uptake in both skeletal muscle and adipose tissue. The net result of these metabolic alterations was a $32 \%$ reduction in serum glucose levels coupled with a $56 \%$ reduction in serum insulin levels. There was also a $69 \%$ elevation in NEFA levels which was likely a result of the reduction of insulin-inhibited lipolysis. The glucose, insulin, and lactate results confirm those previously reported [34]. The reduced level of insulin in transgenics presumably reflects a compensatory mechanism on the part of the beta-cell consequent to an increase in whole-body insulin sensitivity. Studies are currently ongoing to confirm this experimentally. Although the transgenic mice were able to dispose of part of the glucose through enhanced storage as glycogen, the elevation in serum lactate levels suggests that the capacity for this pathway was exceeded. Glycogen levels in fed mice were increased between 2- to 4-fold in liver, and cardiac and gastrocnemius muscles of transgenic mice compared to controls. This may be related to NEFA levels as Jenkins and colleagues [44] have demonstrated that high levels of NEFAs $(4 \mathrm{mmol} / \mathrm{l})$ promote glucose utilization and storage in skeletal muscle. The increase in liver glycogen levels may be a result of the elevated circulating lactate levels, which has been reported to be the primary substrate for hepatic glycogen synthesis [45].

Surprisingly, cardiac glycogen levels in fasted transgenic mice were elevated above those observed in either fed transgenic or in fed or fasted control mice. The combination of enhanced GLUT 4 expression in cardiac muscle along with the suppression of phosphofructokinase (PFK) activity which occurs in the fasted state [45] possibly account for this observation. GLUT 4 expression in these transgenic animals is substantially higher in heart than in hindlimb muscle (C. Isaacson and P. Bell, unpublished observations). This enhanced po- 
tential for glucose transport could drive the flux of glucose towards the production of glucose 6-phosphate. In the fed state, glycolysis would serve as the principal pathway for glucose 6-phosphate metabolism. However, in the fasted state when energy requirements are satisfied by ketone and fatty-acid oxidation, inhibition of PFK by elevated citrate levels would decrease basal glycolysis and favour glycogenesis. Plasma glucose concentration was low during fasting but due to the combination of increased glucose transport, the lack of glucose-6-phosphatase in muscle, and the inhibition of PFK, glycogenesis presumably becomes the dominant route of glucose disposal in cardiac tissue. Inhibition of hexokinase activity by high levels of glucose 6-phosphate has been reported [46], and although glucose-6-phosphate was not measured in this study, the marked glycogen accumulation argues against a major effect of feedback inhibition.

Basal glucose uptake tended to be elevated in isolated soleus muscle and was significantly higher in adipocytes from transgenic mice. Glucose uptake in both tissues could be further stimulated by insulin resulting in a maximal uptake rate which was additive with the maximal rate observed for control littermates. These data demonstrate that the human GLUT 4 transporter protein was functional in transgenic mice resulting in the constitutive elevation of glucose transport. This observation is in agreement with an earlier study which found that overexpression of GLUT 4 under the control of the fat-specific aP2 promoter results in a dramatic enhancement of basal glucose transport [47] and suggests that overexpression may have saturated the intracellular pool of GLUT 4 resulting in plasma membrane targeting. Although the data indicate that this transporter was responsive to insulin, they do not provide evidence as to its cellular localization. Studies are currently in progress to assess this issue, and to determine if recruitment to the plasma membrane occurs following insulin stimulation.

Alterations in muscle GLUT 4 levels in diabetes and obesity tend to be modest relative to changes in adipose tissue. Some animal models of diabetes and obesity, such as the Zucker Diabetic Fatty (ZDF) or streptozotocin-induced diabetic rats show reduced GLUT 4 levels in muscle $[48,49]$, while others show no changes compared to controls [50]. In NIDDM patients, Pedersen and colleagues [30] found no changes in GLUT $4 \mathrm{mRNA}$ or protein levels compared to lean or obese controls. As noted by Klip and associates some of the differences may be accounted for by translocation [51]. Measurement of total number of glucose transporters may not reflect actual recruitment to the membrane. It is also clear that factors such as muscle fiber type [49] and diet [26] may influence GLUT 4 expression and thus further complicate comparisons between studies.
Recently, several laboratories have begun to characterize lines of transgenic mice overexpressing either GLUT 1 or GLUT 4 glucose transporters [47, 52-54]. As in the present study, GLUT 1 transgenic mice also showed reduced glucose levels, but alternatively insulin levels were normal [52]. Furthermore, basal 2-deoxyglucose uptake in isolated muscles was substantially increased compared to controls [52]. These results would be predicted since GLUT 1 is considered to be the basal glucose transporter. Further, considering that GLUT 4 is the insulin-responsive glucose transporter, it is perhaps not surprising that GLUT 4 transgenic mice would show elevations in insulin-stimulated but not in basal glucose transport in muscle. Alternatively, the present results also demonstrated that both basal and insulin-stimulated glucose transport were elevated in adipose tissue. This was also observed in a recent report of transgenic mice overexpressing GLUT 4 selectively in fat [47]. In these mice, fasting glucose levels were decreased $(\sim 20 \%)$ and insulin levels were unchanged in the fasted state but were decreased $(\sim 40 \%$ in the fed state; [47]).

In summary, carbohydrate metabolism has been described in a unique animal model of GLUT 4 overexpression. The results indicate that overexpression of the GLUT 4 glucose transporter in mice produced a pronounced increase in glucose utilization with an overall reduction in glucose and insulin levels. Thus, the data indicate that modest enhancements in GLUT 4 levels could serve as an approach for potential treatment for insulin resistance of diabetes.

Acknowledgements. The authors would like to thank Ms. B.A. Battle, Ms. D. Barilla, and Ms. M. A. Valentin for expert technical assistance and Dr. B.E. Dunning for the analysis of insulin levels.

\section{References}

1. DeFronzo RA (1988) The triumvirate: $\beta$-cell, muscle, liver. A collusion responsible for NIDDM. Diabetes 37: 667-687

2. Kolterman OG, Gray RS, Griffin J, Burstein P, Insel J, Scarlett JA, Olefsky JM (1981) Receptor and postreceptor defects contribute to the insulin resistance in noninsulin-dependent diabetes mellitus. J Clin Invest 68: 957-969

3. Garvey WT, Maianu L, Huecksteadt TP, Birnbaum MJ, Molina JM, Ciaraldi TP (1991) Pretranslational suppression of a glucose transporter protein causes insulin resistance in adipocytes from patients with non-insulin-dependent diabetes mellitus and obesity. $\mathbf{J}$ Clin Invest 87: 10721081

4. Sinha MK, Raineri-Maldonado C, Buchanan C, Pories WJ, Carter-Su C, Pilch PF, Caro JF (1991) Adipose tissue glucose transporters in NIDDM: decreased levels of muscle/ fat isoform. Diabetes 40: 472-477

5. Foley JE (1988) Mechanisms of impaired insulin action in isolated adipocytes from obese and diabetic subjects. Diabetes Metab Rev 4: 487-505 
6. Ramlal T, Rastogi S, Vranic M, Klip A (1989) Decrease in glucose transporter number in skeletal muscle of mildly diabetic (streptozotocin-treated) rats. Endocrinology 125: 890-897

7. Wallberg-Henriksson H, Holloszy JO (1985) Activation of glucose transport in diabetic muscle: responses to contraction and insulin. Am J Physiol 249: C233-C237

8. Pessin JE, Bell GI (1992) Mammalian facilitative glucose transporter family: structure and molecular regulation. Annu Rev Physiol 54: 911-930

9. Bell GI, Burant CF, Takeda J, Gould GW (1993) Structure and function of mammalian facilitative sugar transporters. J Biol Chem 268 19161-19164

10. James DE, Brown R, Navarro J, Pilch PF (1988) Insulinregulatable tissues express a unique insulin-sensitive glucose transport protein. Nature 333: 183-185

11. Zorzano A, Wilkinson W, Kotliar N, Thoidis G, Wadzinkski BE, Ruoho AE, Pilch PF (1989) Insulin-regulated glucose uptake in rat adipocytes is mediated by two transporter isoforms present in at least two vesicle populations. J Biol Chem 264: 12358-12363

12. Holman GD, Kozka IJ, Clark AE et al. (1990) Cell surface labelling of glucose transporter isoform GLUT 4 by bismannose photolabel. J Biol Chem 265: 18172-18179

13. Cushman SW, Wardzala LJ (1980) Potential mechanism of insulin action on glucose transport in the isolated rat adipose cell. J Biol Chem 255: 4748-4762

14. Suzuki K, Kono T (1980) Evidence that insulin causes translocation of glucose transport activity to the plasma membrane from an intracellular storage site. Proc Natl Acad Sci USA 77: 2542-2545

15. Klip A, Ramlal T, Young DA, Holloszy JO (1987) Insulin induced translocation of glucose transporters in rat hindlimb muscles. FEBS Lett 224: 224-230

16. Douen AG, Ramlal T, Klip A, Young DA, Cartee GD, Holloszy JO (1989) Exercise-induced increase in glucose transporters in plasma membranes of rat skeletal muscle. Endocrinology 124: 449-454

17. Laurie SM, Cain CC, Lienhard GE, Castle JD (1993) The glucose transporter GLUT 4 and secretory carrier membrane proteins (SCAMPs) colocalize in rat adipocytes and partially segregate during insulin stimulation. J Biol Chem 268: 19110-19117

18. Etgen GJ, Memon AR, Thompson GA, Ivy Jl (1993) Insulin- and contraction-stimulated translocation of GTP-binding proteins and GLUT 4 protein in skeletal muscle. J Biol Chem 268: 20164-20169

19. Cormont M, Tanti JF, Zahraoui A, Van Obberghen E, Tavitian A, Marchand-Brustel Y (1993) Insulin and okadaic acid induce rab4 redistribution in adipocytes. $\mathrm{J}$ Biol Chem 268: 19491-19497

20. Rodnick KJ, Slot JW, Studelska DR, Hanpeter DE, Robinson LJ, Geuze HJ, James DE (1992) Immunocytochemical and biochemical studies of GLUT 4 in rat skeletal muscle. J Biol Chem 267: 6278-6285

21. Slot JW, Geuze HJ, Gigengack S, James DE, Lienhard GE (1991) Translocation of the glucose transporter GLUT 4 in cardiac myocytes of the rat. Proc Natl Acad Sci USA 88: 7815-7819

22. Slot JW, Geuze HJ, Gigengack S, Lienhard GE, James DE (1991) Immunolocalization of the insulin regulatable glucose transporter in brown adipose tissue of the rat. $\mathrm{J}$ Cell Biol 113: 123-135

23. Kahn BB, Charron MJ, Lodish HF, Cushman SW, Flier JS (1989) Differential regulation of two glucose transporters in adipose cells from diabetic and insulin-treated diabetic rats. J Clin Invest 84: 404-411
24. Kahn BB, Rosetti L, Lodish HF, Charron MJ (1991) Decreased in vivo glucose uptake but normal expression of GLUT1 and GLUT 4 in skeletal muscle of diabetic rats. J Clin Invest 87: 2197-2206

25. Slieker LJ, Sundell KL, Heath WF, Osborne HE, Bue J, Manetta J, Sporstman JR (1992) Glucose transporter levels in tissues of spontaneously diabetic Zucker fa/fa rat (ZDF/ $\mathrm{drt}$ ) and viable yellow mouse (Av/a). Diabetes 41: 187-193

26. Kahn BB, Pedersen O (1993) Suppression of GLUT 4 expression in skeletal muscle of rats that are obese from high fat feeding but not from high carbohydrate feeding or genetic obesity. Endocrinology 132: 13-22

27. King PA, Horton ED, Hirshman MF, Horton ES (1992) Insulin resistance in obese Zucker rat (fa/fa) skeletal muscle is associated with a failure of glucose transporter translocation. J. Clin Invest 90: 1568-1575

28. Yamamoto T, Fukumoto H, Koh G et al. (1991) Liver and muscle-fat type glucose transporter gene expression in obese and diabetic rats. Biochem Biophys Res Comm 175: $995-1002$

29. Friedman JE, Sherman WM, Reed MJ, Elton CW, Dohm GL (1990) Exercise training increases glucose transporter protein GLUT 4 in skeletal muscle of obese Zucker (fa/fa) rats. FEBS Lett 268: 13-16

30. Pedersen O, Bak JF, Andersen PH, Lund S, Moller DE, Flier JS, Kahn BB (1990) Evidence against altered expression of GLUT1 or GLUT 4 in skeletal muscle of patients with obesity or NIDDM. Diabetes 39: 865-870

31. Handberg A, Vaag A, Damsbo P, Beck-Nielsen H, Vinten J (1990) Expression of insulin regulatable glucose transporters in skeletal muscle from type 2 (non-insulin-dependent) diabetic patients. Diabetologia 33: 625-627

32. Garvey WT, Maianu L, Hancock JA, Golichowski AM, Baron A (1992) Gene expression of GLUT 4 in skeletal muscle from insulin-resistant patients with obesity, IGT, GDM, and NIDDM. Diabetes 41: 465-475

33. Koranyi LI, Bourey RE, Vuorinen-Markkola H, Koivisto VA, Permutt MA, Yki-Järvinen H (1991) Level of skeletal muscle glucose transporter protein correlates with insulinstimulated whole-body glucose disposal in man. Diabetologia 34: 763-765

34. Chu DT, Isaacson CM, Swanson ME, Buerki K, Bruns C, Dunning BE, Bell PA (1992) Expression of human GLUT 4 glucose transporters in transgenic mice results in hypoglycemia. Diabetes 41: 144A (Abstract)

35. Davis LG, Dibner MD, Battey JF (1986) Basic methods in molecular biology. Appleton and Lange, Norwalk CT

36. Young DA, Deems RO, Deacon RW, McIntosh RH, Foley JE (1990) Effects of amylin on glucose metabolism and glycogenolysis in vivo and in vitro. Am J Physiol 259: E457E461

37. Young DA, Uhl JJ, Cartee GD, Holloszy JO (1986) Activation of glucose transport in muscle by prolonged exposure to insulin. J Biol Chem 261: 16049-16053

38. Rodbell M (1964) Metabolism of isolated fat cells. J Biol Chem 239: 375-380

39. Honnor RC, Dhillon GS, Londos C (1985) cAMP-dependent protein kinase and lipolysis in rat adipocytes. J Biol Chem 260: 15122-15129

40. Moody AJ, Stan MA, Stan M, Gliemann J (1974) A simple free fat cell bioassay for insulin. Horm Metab Res 6: 12-16

41. Deems RO, Cardinaux F, Deacon. RW, Young DA (1991) Amylin or CGRP (8-37) fragments reverse amylin-induced inhibition of ${ }^{14} \mathrm{C}$-glycogen accumulation. Biochem Biophys Res Commun 181(1): 116-120

42. Chan TM, Exton JH (1976) A rapid method for the determination of glycogen content and radioactivity in small 
quantities of tissue or isolated hepatocytes. Anal Biochem 71: 96-105

43. Bradford MM (1976) A rapid and sensitive method for the quantitation of microgram quantities of protein utilizing the principle of dye binding. Anal Biochem 72: 248-254

44. Jenkins AB, Storlien LH, Chisholm DJ, Kraegen EW (1988) Effects of nonesterified fatty acid availability on tissue-specific glucose utilization in rats in vivo. J Clin Invest 82: 293-299

45. Rognstad R (1989) Errors in the isotopic estimations of hepatic glycogen synthesis and glucose output. Metabolism 38: 619-624

46. Randle P, Kerbey A, Espinal J (1988) Mechanisms decreasing glucose oxidation in diabetes and starvation: role of lipid fuels and hormones. Diabetes Metab Rev 4: 623-638

47. Shepherd PR, Gnudi L, Tozzo E, Yang H, Leach F, Kahn BB (1993) Adipose cell hyperplasia and enhanced glucose disposal in transgenic mice overexpressing GLUT 4 selectively in adipose tissue. J Biol Chem 268: 22243-22246

48. Strout HV, Vicario PP, Biswas C, Saperstein R, Brady EJ, Pilch PF, Berger J (1990) Vanadate treatment of streptozotocin diabetic rats restores expression of the insulin-responsive glucose transporter in skeletal muscle. Endocrinology $126: 2728-2732$
49. Friedman JE, De Vente JE, Peterson RG, Dohm GL (1991) Altered expression of muscle glucose transporter GLUT-4 in diabetic fatty Zucker rats (ZDF/Drt-fa). Am J Physiol 261: E782-E788

50. Koranyl L, James DE, Mueckler M, Permutt MA (1990) Rate-limiting steps for insulin-mediated glucose uptake into perfused rat hindlimb. J Clin Invest 85: 962-967

51. Klip A, Marette A, Dimitrakoudis D, Ramlal T, Giacca A, Shi ZQ, Vranic M (1992) Effect of diabetes on glucoregulation. Diabetes Care 15: 1747-1766

52. Ren JM, Marshall BA, Gulve EA, Gao J, Johnson DW, Holloszy JO, Mueckler M (1993) Evidence from transgenic mice that glucose transport is rate-limiting for glycogen deposition and glycolysis in skeletal muscle. J Biol Chem 268: 16113-16115

53. Liu ML, Olson AL, Moye-Rowley WS, Buse JB, Bell GI, Pessin JE (1992) Expression and regulation of the human GLUT 4/muscle-fat facilitative glucose transporter gene in transgenic mice. J Biol Chem 267: 11673-11676

54. Ezaki O, Flores-Riveros JR, Kaestner KH, Gearhart J, Lane DM (1993) Regulated expression of an insulin-responsive glucose transporter (GLUT 4) minigene in 3T3L1 adipocytes and transgenic mice. Proc Natl Acad Sci 90: 3348-3352 